\title{
The Occurrence of Salmonella in Airline Meals
}

\author{
By $M$. Hatakka and K. Asplund \\ Department of Food and Environmental Hygiene, College of Veterinary Medicine, Helsinki and Medical De- \\ partment, Finnair, Vantaa, Finland.
}

\begin{abstract}
Hatakka, M. and K. Asplund: The occurence of Salmonella in airline meals. Acta vet. scand. 1993, 34, 391-396. - The occurrence of Salmonella in airline meals was studied in 1989-1992. Samples were collected from flight kitchens in 29 countries. The material consisted of 400 cold dishes and 1,288 hot dishes as well as salads, cheese plates and desserts. Total number of samples was 2211. Salmonella spp. were isolated from 6 samples; 1 contaminated sample was a cold dish prepared in Bangkok, 1 was a hot dish prepared in Mombasa and the remaining 4 contaminated samples were hot dishes prepared within one week in Beijing. The isolated serotypes were $S$. ohıo, S. manchester and $S$. braenderup. The contaminated cold dish prepared by a flight kitchen in Bangkok was found to be connected with a Salmonella outbreak which occurred in Finland in 1990. Cold airline dishes containıng food of animal origın seems to be more risky as a source of Salmonella infections among airlıne passengers.
\end{abstract}

flight kitchen; travel catering.

\section{Introduction}

According to Tauxe et al. (1987) at least 23 outbreaks of foodborne illness involving 120 commercial airline flights were reported between 1947 and 1984 in the world. Salmonella was the most common pathogen in those incidents, causing 7 outbreaks; it was followed by Staphylococcus, causing 5 outbreaks, and Vibrio species, also causing 5 outbreaks. Salmonellosis is the main foodborne disease in many countries (Bryan 1981, Todd 1983, Perez et al. 1986, Pöhn \& Grossman 1986). A Salmonella outbreak always causes considerable financial losses. In 1989, Todd reported preliminary estimates of the cost of foodborne diseases in the United States. He found that, from an economical point of view, salmonellosis was the most important foodborne disease, entailing to a total annual cost of $\$ 4$ billion.

Munce (1986) studied approx. 6,000 food samples collected from flight kitchens in 40 worldwide locations. Salmonella was isolated from approx. $1 \%$ of the samples. The most frequent isolations were made from airline food prepared in India and Indonesia. In a survey of 567 airline meals at Heathrow Airport, carried out in $1984-86,0.5 \%$ of meals were found to contain Salmonella (Roberts \& Gilbert 1986). A Finnish study of airline meals (991 samples) prepared in 23 different countries, carried out in 1986-90, revealed $0.2 \%$ Salmonella positive meals (Hatakka \& Korkeala 1990).

According to Tauxe et al. (1987) the largest reported Salmonella outbreak associated with airline meals infected 550 out of 2,500 passengers $(22 \%)$ in 1976 . Six passengers died in the course of this outbreak. The survey revealed that the infection was caused by $S$. typhimurium, and that the vehicle of the infection was an egg salad, prepared in a Spanish flight kitchen. 
Table 1. The number of airline meal samples examined for Salmonella, by the country where the meals were prepared, 1989-1992. (The number of Salmonella positive samples).

\begin{tabular}{|c|c|c|c|c|c|c|}
\hline Country & $\begin{array}{l}\text { Hot } \\
\text { dish }\end{array}$ & $\begin{array}{l}\text { Cold } \\
\text { dish }\end{array}$ & $\begin{array}{l}\text { Cheese } \\
\text { plate }\end{array}$ & Salad & Dessert & Total \\
\hline \multicolumn{7}{|l|}{ Africa } \\
\hline Egypt & 13 & 9 & 0 & 0 & 5 & 27 \\
\hline Kenya & $10(1)$ & 6 & 0 & 1 & 5 & 22 \\
\hline \multicolumn{7}{|l|}{ America } \\
\hline Barbados & 5 & 3 & 0 & 3 & 3 & 14 \\
\hline Canada & 3 & 4 & 0 & 0 & 3 & 10 \\
\hline Dominican Republic & 4 & 3 & 0 & 2 & 2 & 11 \\
\hline Mexico & 3 & 2 & 0 & 2 & 2 & 9 \\
\hline United States & 8 & 2 & 0 & 0 & 0 & 10 \\
\hline \multicolumn{7}{|l|}{ Asia } \\
\hline China & $60(4)$ & 39 & 0 & 15 & 22 & 136 \\
\hline Japan & 8 & 4 & 0 & 4 & 4 & 20 \\
\hline Malaysia & 11 & 9 & 0 & 9 & 9 & 38 \\
\hline Thailand & 22 & $12(1)$ & 0 & 5 & 8 & 47 \\
\hline \multicolumn{7}{|l|}{ Europe } \\
\hline Austria & 2 & 0 & 0 & 1 & 1 & 4 \\
\hline Belgium & 7 & 2 & 3 & 2 & 2 & 16 \\
\hline Cyprus & 2 & 0 & 0 & 2 & 2 & 6 \\
\hline Denmark & 0 & 6 & 0 & 0 & 0 & 6 \\
\hline Germany & 25 & 12 & 3 & 9 & 22 & 71 \\
\hline Finland & 994 & 227 & 6 & 178 & 72 & 1,477 \\
\hline France & 4 & 2 & 0 & 1 & 2 & 9 \\
\hline Greece & 16 & 3 & 0 & 11 & 9 & 39 \\
\hline Hungary & 2 & 2 & 0 & 0 & 0 & 4 \\
\hline Italy & 14 & 4 & 0 & 10 & 9 & 37 \\
\hline The Netherlands & 5 & 0 & 0 & 0 & 0 & 5 \\
\hline Norway & 0 & 2 & 0 & 0 & 0 & 2 \\
\hline Portugal & 8 & 7 & 0 & 0 & 3 & 18 \\
\hline Spain & 37 & 19 & 1 & 11 & 18 & 86 \\
\hline Sweden & 1 & 9 & 0 & 1 & 1 & 12 \\
\hline Switzerland & 6 & 0 & 2 & 1 & 8 & 17 \\
\hline Turkey & 13 & 3 & 3 & 9 & 9 & 37 \\
\hline United Kingdom & 5 & 9 & 1 & 1 & 5 & 21 \\
\hline Total & $1,288(5)$ & $400(1)$ & 19 & 278 & 226 & 2,211 \\
\hline
\end{tabular}

Tauxe et al. (1987) reported that, in 1984, $S$. enteritidis had infected several passengers on 29 flights from London to the United States, the vehicle then being contaminated airline meals. A widespread outbreak of $S$. infantis, traced to food prepared in a Finnish flight kitchen, occurred in Finland in 1986 (Hatakka
1992). The number of persons at risk was 1122 including 350 airline passengers. On the basis of microbiological investigations, a total of $226(20 \%)$ persons became infected, from which 91 were airline passengers. Food prepared by the flight kitchen in Palma de Mallorca was shown to have been the source of an 
S.enteritidis outbreak infecting 71 passengers in 1989 (Jahkola 1989).

The meals served on aircraft entail the risk that airline passengers may become infected by Salmonella. The strict hygiene requirements set for flight kitchens constitute a basis for safe airline meals. The purpose of this study was to examine the occurrence of Salmonella in different meals prepared in flight kitchens located in various countries.

\section{Materials and methods \\ Samples}

The material was collected in 1989-1992. Altogether 2,211 airline meals were examined. The material consisted of 400 cold dishes, 1,288 hot dishes, 278 salads, 19 cheese plates and 226 desserts. Out of the 2,211 samples, 1,477 were gathered from 2 Finnish flight kitchens, the remaining 734 being sampled worldwide from flight kitchens located in 28 countries. The number of samples by the country and meals are shown in Table 1 . The analysis was carried out from routine samples taken according to the control programme of the Finnish airline company, Finnair. The samples were stored in isolated boxes with dry ice during the flight to Finland and were kept frozen until the examination began. The Finnish samples were not frozen. The samples were examined at Vantaa Food and Environmental Laboratory.

\section{Isolation of Salmonella}

The isolation procedure was based on the method of Nordic Committee on Food Analysis (Anon. 1991). The sample for Salmonella analysis contained all different meal ingredients, altogether $25 \mathrm{~g}$. The sample was transferred to $225 \mathrm{ml}$ of buffered peptone water (Difco, Detroit MI, USA) and incubated for
$24 \mathrm{~h}$ at $37^{\circ} \mathrm{C}$. After pre-enrichment, $10 \mathrm{ml}$ of the culture was transferred to $90 \mathrm{ml}$ of tetrathionate broth (LAB M, Bury, England) and 0.1 $\mathrm{ml}$ of the culture to $10 \mathrm{ml}$ of Rappaport-Vassiliadis broth (Oxoid, CM 866, Hampshire, England). Tetrathionate broth was incubated for $24 \mathrm{~h}$ at $37^{\circ} \mathrm{C}$ and Rappaport-Vassiliadis broth for $24 \mathrm{~h}$ at $41.5^{\circ} \mathrm{C}$. After incubation, each enrichment broth was streaked on culture media. Two different plating media were used; bromthymolblue-lactose-saccharoseagar (Orion Diagnostica, Espoo, Finland) and Salmonella agar according to Önöz (Merck 15034, Darmstadt, Germany) until September 1990 , when bromthymolblue-lactose-saccharose-agar was changed to brilliant-greenphenolred-agar (Orion Diagnostica). Bromthymolblue-lactose-saccharose-agar and brilliant-green-agar were incubated for $24 \mathrm{~h}$ at $37^{\circ} \mathrm{C}$ and Önöz agar for $48 \mathrm{~h}$ at $37^{\circ} \mathrm{C}$. Two to 6 suspected colonies from each plate were inoculated into triple-sugar-iron-agar (Difco) and on to urea-agar (Difco). The serotyping of the Salmonella isolates was carried out by the $\mathrm{Na}$ tional Salmonella Centre, National Public Health Institute, Finland, using the method of Kauffman (1966).

\section{Results}

Six $(0.3 \%)$ out of the total of 2,211 samples tested were found to be Salmonella positive. Salmonella was not detected in the 1,477 samples prepared in 2 Finnish flight kitchens. Out of the 734 samples prepared in other flight kitchens, located in 28 countries, 6 $(0.8 \%)$ were positive. Isolations of salmonellae were made from meals prepared in 2 Asian countries, Thailand and China, and in 1 African country, Kenya (Table 1). Five of the total 1,288 hot dishes $(0.4 \%)$ and 1 of the total 400 cold dishes $(0.3 \%)$ examined were Salmonella positive. 
Table 2. Salmonella serotypes isolated from airline meals in 1989-1992.

\begin{tabular}{lll}
\hline Meal & Flight kitchen & Serotype \\
\hline Cold dish, ham & Bangkok & S. ohıo \\
Hot dish, chicken & Beijing & S. braenderup \\
Hot dish, beef & Beijing & S. braenderup \\
Hot dish, fish & Beijing & S. braenderup \\
Hot dish, crepes & Beijing & S. braenderup \\
Hot dish, beef & Mombasa & S. manchester \\
\hline
\end{tabular}

The first positive sample, isolated from a cold dish prepared in a flight kitchen in Bangkok, was found in February 1990. It contained ham, Edam-type cheese, boiled egg and cooked and marinated vegetables. The serotype was $S$. ohio (Table 2). The second occurrence of Salmonella bacteria was in samples taken between 27 July and 3 August 1990 from Beijing in China. Salmonella was isolated from 4 different hot meals, the serotype being the same in all 4 samples, $S$. braenderup (Table 2). The first hot dish contained chicken, mashed potatoes and beans; the second beef, mashed potatoes and cooked vegetables; the third fish, rice and cooked vegetables and the fourth was snack crepes. In January 1991, Salmonella was isolated from a hot dish prepared in Mombasa, Kenya. The dish consisted of beef, potatoes and cooked vegetables. The serotype isolated was $S$. manchester (Table 2).

The positive isolations made using 2 enrichment broths and 2 plating media are shown in Table 3. From the 6 positive samples detected, 5 were found with Rappaport-Vassiliadis broth while 3 were found with tetrathionate broth. One sample was positive only after enrichment in tetrathionate broth. The reliability of the results was better by using 2 different enrichment broths. Salmonella agar according to Önöz produced more isolations than the other 2 plating media.
Salmonella bacteria were not found in any cheese plates, salads or desserts studied (Table 2).

\section{Discussion}

Salmonella was isolated from $0.3 \%$ of all airline meals sampled from 29 different countries and examined in 1989-1992. The frequency of Salmonella in this study was similar to that detected in a study done in Finland in 1986-1990 (Hatakka \& Korkeala 1990), where $0.2 \%$ out of 991 samples prepared in 23 different countries were found to be positive for salmonellae. The occurrence of Salmonella in the present study was somewhat lower than that in surveys carried out by Munce (1986) and Roberts \& Gilbert (1986), who detected Salmonella in $1 \%$ and $0.5 \%$ of airline meals, respectively. If we exclude the samples from Finnish flight kitchens, the $0.8 \%$ rate of $\mathrm{Sal}$ monella positive samples detected in this study falls between the values reported by Munce (1986) and by Roberts \& Gilbert (1986).

The 6 Salmonella isolations made in this survey were from meals prepared in 3 different countries, 2 of them located in Asia and 1 in Africa (Table 1). The contaminated airline food detected by Munce (1986) had also been prepared in Asian and African countries. The kitchens were located in Fiji, Hongkong, India, Indonesia, The Philippines, Thailand and Zimbabwe. The survey carried out by Roberts \& Gilbert (1986) reported an occurrence of $0.5 \%$ of Salmonella in airline meals prepared at 10 British catering facilities serving the majority of airlines at London (Heathrow) Airport. This study also indicates that airline meals prepared in Asian and African countries seem to have a higher risk of contamination than meals prepared in Europe and America. 
One of the Salmonella positive findings in this study (S. ohio) was subsequently found to be connected with an outbreak in Finland. The contaminated cold dish was served on a flight from Bangkok to Helsinki on the 15 February 1990. During the following 4 week period, the National Salmonella Centre of Finland recorded that 14 people had been infected by $S$. ohio (Jahkola personal communication 1992). Five passengers' gastrointestinal illness caused by $S$. ohio may have been connected with the cold dish served during the flight mentioned above. Thai authorities informed Finnair of $S$. ohio infections in people in Thailand during February 1990. The aircraft used for the above mentioned flight did not have cold storage facilities. The contamination of the cold dishes together with their transport unchilled during a long-haul flight was considered to have caused this outbreak. In co-operation with the caterer in Thailand, the airline decided to alter the high-risk cold food containing protein by removing the ham from the portion.

Foodborne illness was not found to be associated with positive findings in hot meals prepared by Beijing flight kitchen personnel between the 27 July and 3 August 1990 . The serotype isolated from the 4 Beijing meals was the same, $S$. braenderup. The fact that different hot meals prepared on different days were contaminated by the same serotype may indicate that there was a carrier among food handlers or that the surfaces and facilities of the kitchen were contaminated. The hot meal prepared by a flight kitchen in Mombasa was not linked with foodborne illness among airline passengers after a charter flight from Mombasa to Helsinki.

All samples from salads were negative for Salmonella. Many international flight kitchens disinfect salad ingredients, such as lettuce, tomato and cucumber before preparing fresh
Table 3. Salmonella isolations with different enrichment broths and platıng media.

\begin{tabular}{|c|c|c|c|c|}
\hline \multirow[t]{2}{*}{ Salmonella serotype } & \multicolumn{4}{|c|}{ Enrichment broth } \\
\hline & \multicolumn{2}{|c|}{ TT } & \multicolumn{2}{|c|}{ RV } \\
\hline S. ohıo & S- & $\mathrm{O}+$ & $\mathbf{S}+$ & $\dot{\mathrm{O}}+$ \\
\hline S. braenderup & & & & \\
\hline chicken & S- & $\mathrm{O}_{-}$ & $\mathrm{S}+$ & $\mathrm{O}+$ \\
\hline snack & $\mathrm{S}-$ & $\mathrm{O}-$ & $\mathrm{S}+$ & $\mathrm{O}+$ \\
\hline beef & S- & $\mathrm{O}+$ & $\mathrm{S}_{+}$ & $\mathrm{O}+$ \\
\hline fish & $\mathrm{S}-$ & $\mathrm{O}-$ & $\mathrm{S}+$ & $\mathrm{O}+$ \\
\hline S. manchester & B- & $\mathrm{O}+$ & B- & $\mathrm{O}-$ \\
\hline
\end{tabular}

TT = Tetrathionate broth

$\mathrm{RV}=$ Rappaport-Vassiliadis broth

$\mathrm{S}$ = Bromthymolblue-lactose-saccharose-agar

$\mathrm{O}=$ Salmonella agar according to Onoz

$\mathrm{B}=$ Brilliantgreen-phenolred-agar

+ detected, - not detected

salad for airlines. As Asplund \& Nurmi (1991) have shown, tomatoes stored at room temperature may be a possible vehicle of Salmonella spp. Disinfection may be an effective procedure for preventing Salmonella infections originating in salads. Likewise, Salmonella bacteria were not found in dessert samples. The reason may be that menu selection takes care of avoiding high risk desserts. Most of the desserts involved in this material were fresh fruits.

The presence of Salmonella bacteria in airline meals always presents a health risk for passengers and crew. Strict hygiene requirements must be enforced during the preparation, transport and serving of food for aircraft. In this study, Salmonella bacteria were isolated from cold and hot meals. The Salmonella positive finding from the cold dish only was confirmed to be connected with a foodborne outbreak. The risk of being infected by cold, especially protein containing airline meals is often connected with warm climate, long-haul flights and a shortage of refrigeration facilities at airports and on aircraft. Im- 
portant factors to prevent Salmonella infections via hot dishes are fast chilling after preparing, chilled transport and storage with sufficient heat treatment on aircraft before serving.

\section{Acknowledgements}

This study was supported by The Finnish Veterinary Science Foundation. The authors would like to thank the staff of the Food and Environmental Laboratory of the City of Vantaa for technical assistance, and Professor Hannu Korkeala for his valuable criticism of the manuscript.

\section{References}

Anonymous: Salmonella bacteria. Detection in foods. Nordic Committee on Food Analysis. $\mathrm{Nr}$ 71, 1991.

Asplund K, Nurmi E: The growth of Salmonella in tomatoes. Int. J. Food Microbiol. 1991, 13, 177-182.

Bryan LB: Current trends in foodborne salmonellosis in the United States and Canada. J. Food Protect. 1981, 44, 394-401.

Hatakka M: Salmonella outbreak among railway and airline passengers. Acta vet. scand. 1992, 33, 253-260.

Hatakka M, Korkeala H: The occurrence of Salmonella in airline meals. Food Micro 90. Abstracts. The 14th International Symposium of The International Committee on Food Microbiology and Hygiene, Bỏlkesjo, Norway, 1990, p. 60.

Jahkola M: Salmonella enteritıdis outbreak traced to airline food. WHO Surveillance Programme for Control of Foodborne Infections and Intoxications in Europe. Newsletter, $\mathrm{Nr} 22$. Institute of Veterınary Medicine-Robert von Ostertag-Institute, Berlın, Germany. 1989, p. 3.

Kauffman F: The Bacteriology of Enterobacteriaceae Munsgaard, Copenhagen. 1966, 400 pp.

Munce BA: Salmonella serotypes from international hotel and airline food. In: Proc. 2nd World Congress Foodborne Infections and Intoxications. Institute of Veterinary Medicine-Robert von Ostertag-Institute, Berlın, Germany. 1986, pp. 705-708.
Perez J, Tello O, Mata M, Fuente J: Foodborne infections and intoxications - outbreaks evolution in Spain 1976-1984. In: Proc. 2nd World Congress Foodborne Infections and Intoxications. Institute of Veterinary Medicine-Robert von Ostertag-Institute, Berlin, Germany. 1986, pp. 104109.

Pohn HP, Grossman R: Outbreaks of foodborne diseases in Federal Republic of Germany 19831985. In: Proc. 2nd World Congress Foodborne Infections and Intoxications. Institute of Veter1nary Medicıne-Robert von Ostertag-Institute, Berlin, Germany. 1986, pp. 99-103.

Roberts D, Gilbert RJ: Microbiology of airline meals. In: Proc. 2nd World Congress Foodborne Infectons and Intoxications. Institute of Veternnary Medicine-Robert von Ostertag-Institute, Berlin, Germany. 1986, pp. 701-704.

Tauxe RV, Torney MP, Mascola L, Hargrett-Bean NT Blake PA: Salmonellosis outbreak on transatlantic flights: Foodborne illness on aircraft 19481984. Amer. J. Epidemiol. 1987, 125, 150-157.

Todd ECD $\cdot$ Foodborne disease in Canada - a 5-year summary. J. Food Protect. 1983, 46, 650-657.

Todd ECD. Preliminary estimates of costs of foodborne disease in the United States. J. Food Protect. 1989, 52, 595-601.

\section{Sammanfattning \\ Forekomst av Salmonella i flygplansmåltıder.}

Forekomsten av Salmonella i flygplansmåltider undersóktes 1989-1992. Prov togs från flygkok 129 lander. Undersoknningsmaterialet bestod av 400 portıoner kallrảtt och 1,288 portioner såval varmratt som sallader, ostbrickor och desserter. Salmonella påvisades 16 prov; 1 kontaminerat prov harstammade från en kallrätt tillredd i Bangkok, 1 från en varmratt tillredd 1 Mombasa och de resterande 4 proven hảrrorde från ratter tillredda i Peking. De isolerade serotyperna var $S$. ohı, S. manchester och $S$. braenderup. Den kontamınerade kallratten från Bangkok kunde kopplas till en Salmonella epidemi i Finland 1991. Kallrätter av animaliskt ursprung ar risklivsmedel som utgor en kálla till Salmonella infectioner hos flygresenärer.

(Recelved February 14, 1993; accepted June 21, 1993).

Reprints may be requested from: M. Hatakka, Food and Environmental Laboratory, Viertolankuja 4 A, SF01300 Vantaa, Finland. 